\title{
Effect of infusion of PGI-2, 6-keto-PGF-1 $\alpha$ and PGF-2 $\alpha$ on luteal function in the pregnant rat
}

\author{
K. M. Henderson* $†$, D. L. Willcox $\ddagger$ and N. W. Bruce $\ddagger$ \\ Raine Research Centre for the Study of Perinatal and Developmental Biology, Departments of \\ *Biochemistry and $\ddagger$ Anatomy and Human Biology, University of Western Australia, Nedlands, \\ Western Australia 6009
}

\begin{abstract}
Summary. Prostacyclin (PGI-2), 6-keto-PGF-1 $\alpha$ and PGF-2 $\alpha$ were infused continuously for $6 \mathrm{~h}$ into the dorsal aorta of rats 8 days pregnant. PGF- $2 \alpha(10 \mu \mathrm{g} / \mathrm{h})$ significantly reduced plasma progesterone concentrations by $66 \%$ and luteal tissue concentrations of pregnenolone and progesterone by $78 \%$ and $95 \%$ respectively. Plasma concentrations of $20 \alpha$-dihydroprogesterone remained unchanged whilst luteal tissue concentrations rose 2 -fold. Plasma progesterone concentrations were significantly reduced to $50 \%$ by PGI-2 $(10 \mu \mathrm{g} / \mathrm{h})$ but were unaffected by 6-keto-PGF-1 $\alpha(10$ or $100 \mu \mathrm{g} / \mathrm{h})$. Neither PGI-2 $(10 \mu \mathrm{g} / \mathrm{h})$ nor 6-keto PGF-1 $\alpha(10$ or $100 \mu \mathrm{g} / \mathrm{h})$ had any significant effect on plasma concentrations of $20 \alpha$-dihydroprogesterone or on luteal tissue concentrations of pregnenolone, progesterone or 20 $\alpha$-dihydroprogesterone. Arterial blood pressure was unaffected by PGF- $2 \alpha$ and 6-keto-PGF-1 $\alpha$, but was significantly reduced by PGI-2 at infusion rates $\geqslant 60 \mu \mathrm{g} / \mathrm{h}$.
\end{abstract}

\section{Introduction}

Several studies indicate that prostacyclin (PGI-2) may be involved in the regulation of reproductive processes in the female. It is the prostaglandin present in greatest concentration in the rat ovary and uterus, and the major prostaglandin synthesized by homogenates of these tissues in vitro (Poyser $\&$ Scott, 1980). It is the major product of arachidonic acid metabolism by homogenates of sheep uteri (Jones, Poyser \& Wilson, 1977) and by combined incubations of human endometrium and myometrium (Abel \& Kelly, 1979). PGI-2 has been implicated in the initiation of blastocyst implantation (Kennedy \& Zamecnik, 1978), the regulation of uterine blood flow and menstrual bleeding (Kelly, 1981 ; Smith, Abel, Kelly \& Baird, 1981), and the regulation of follicular blood flow (Veldhuis, Klase \& Demers, 1982). PGI-2 involvement in the regulation of corpus luteum function is possible since it is the principal product of prostaglandin endoperoxide metabolism in luteal tissue of the cow and mare (Sun, Chapman \& McGuire, 1977) and it stimulates adenylate cyclase activity directly in the rabbit corpus luteum (Abramowitz \& Birnbaumer, 1979).

In this study the effect of PGI-2 on luteal function in 8-day-pregnant rats was investigated because at this time the corpora lutea are particularly responsive to prostaglandins (Fuchs, Mok $\&$ Sundaram, 1974).

† Present address: Wallaceville Animal Research Centre, Private Bag, Upper Hutt, New Zealand. 


\section{Materials and Methods}

Prostaglandins. Prostaglandin F-2 $\alpha$ tromethamine (PGF-2 $\alpha$ ), 6-keto-prostaglandin F-1 $\alpha$ and prostacyclin sodium salt (PGI-2) were obtained from the Upjohn Company, Kalamazoo, Michigan, U.S.A. Stock solutions ( 2 or $5 \mathrm{mg} / \mathrm{ml}$ ) of PGF- $2 \alpha$ and 6-keto-PGF-1 $\alpha$ were prepared in ethanol and acetone respectively and stored at $4^{\circ} \mathrm{C}$. Test solutions were prepared on the days of infusion by diluting aliquants of the stock solutions with saline $(9 \mathrm{~g} \mathrm{NaCl} / 1)$ or for $6-\mathrm{keto}-\mathrm{PGF}-1 \alpha$ with saline containing sodium carbonate sufficient to neutralize the prostaglandin. Control rats were infused with saline containing an equivalent amount of organic solvent which never exceeded $1 \%$. Solutions of PGI-2 were prepared immediately before the start of the infusions in $0.05 \mathrm{M}$-Tris$\mathrm{HCl}$ buffer ( $\mathrm{pH} \mathrm{9.4)} \mathrm{and} \mathrm{kept} \mathrm{on} \mathrm{ice} \mathrm{throughout} \mathrm{the} \mathrm{infusion} \mathrm{period.} \mathrm{Control} \mathrm{rats} \mathrm{in} \mathrm{this} \mathrm{group} \mathrm{were}$ infused with Tris- $\mathrm{HCl}$ buffer alone.

Animals and infusion technique. Nulliparous albino Wistar rats, 3-5 months old and weighing $219 \pm 3$ (s.e.m.) g at mating were used. The 55 rats were kept in an environmentally controlled building $\left(17-23^{\circ} \mathrm{C}\right.$, relative humidity 50-70\%, lights from $07: 00$ to $21: 00 \mathrm{~h}$ ). Food and water were freely available. The rats were mated during darkness and the morning on which spermatozoa were found in a vaginal smear was called Day 1 of gestation.

On the morning of Day 8, each rat was anaesthetized with an intraperitoneal injection of pentobarbitone sodium $(40 \mathrm{mg} / \mathrm{kg})$ supplemented by subcutaneous injections $(10 \mathrm{mg} / \mathrm{kg})$ every hour or as needed to maintain the rat in a light surgical plane of anaesthesia. The trachea was cannulated to assist breathing and a cannula was inserted into the dorsal aorta through the left common carotid artery. The arterial cannula was connected to a $T$-piece so that prostaglandin solutions could be infused continuously, except for brief periods of about $30 \mathrm{sec}$ when the flow was interrupted to withdraw blood samples through the arterial cannula. Changes in arterial pressure were monitored by connecting a pressure transducer to the side arm of the T-piece.

When prepared, the rat was placed on an electric heating pad adjusted to maintain rectal temperature at $\sim 35^{\circ} \mathrm{C}$. A prostaglandin solution was then infused into the arterial cannula at a rate of $2 \mathrm{ml} / \mathrm{h}$ for a period of $6 \mathrm{~h}$. Immediately before $(0 \mathrm{~h})$ and at $0 \cdot 5,1,2,3,4,5$ and $6 \mathrm{~h}$ after the start of infusion, blood samples $(0.3 \mathrm{ml}$, except for the final samples when about $1 \mathrm{ml}$ was withdrawn) were taken up into heparinized microhaematocrit tubes, centrifuged, the haematocrit recorded and the plasma removed. Donor blood $(1 \mathrm{ml})$ from rats in dioestrus was given after the $2 \mathrm{~h}$ sampling to compensate for that taken. At the end of the infusion period, each rat was killed with an overdose of pentobarbitone sodium. Both ovaries were removed and the corpora lutea were counted, dissected out, pooled, weighed and homogenized in $5 \mathrm{ml}$ chloroform : methanol $(2: 1 \mathrm{v} / \mathrm{v})$. A single homogenization was found to be sufficient to extract $>99 \%$ of the steroids from the luteal tissue, as assessed by the additional amount of steroid extracted following a 2 nd homogenization in a further $5 \mathrm{ml}$ extractant. The samples of plasma and tissue homogenate were stored at $-16^{\circ} \mathrm{C}$ until analysis.

Radioimmunoassays. Progesterone, 20 $\alpha$-dihydroprogesterone and pregnenolone were measured by radioimmunoassay procedures similar to that described by Thorneycroft \& Stone (1972). Progesterone and 20 $\alpha$-dihydroprogesterone were extracted from plasma before assay with petroleum ether and diethyl ether respectively. The extraction efficiency was monitored by the addition of tritiated steroid $(2000$ c.p.m.) and the mean recoveries were $79 \%$ and $78 \%$ for progesterone and $20 \alpha$-dihydroprogesterone respectively. Preliminary studies indicated that further purification of the organic extracts of plasma and luteal tissue before assay was unnecessary. The coefficient of variation between the values for samples assayed with and without separation of steroids by LH-20 column chromatography as described by Carr, Mikhail \& Flickinger (1971) ranged from 14 to $19 \%$ for all of the assays ( $n=10$ in each instance). Samples were therefore routinely assayed without utilizing a chromatographic step.

Antisera to progesterone (Wallaceville-26) and pregnenolone (Wallaceville-18) were raised in ovariectomized ewes against progesterone-11-hemisuccinate and pregnenolone-3-hemisuccinate conjugated to bovine serum albumin. The $20 \alpha$-dihydroprogesterone antiserum (P20-3) was raised 
in rabbits against 20 $\alpha$-dihydroprogesterone-3-oxime-bovine serum albumin conjugate (Endocrine Sciences, Tarzana, California, U.S.A.). Steroids showing $>1 \%$ cross-reactivity were : $11 \alpha$-hydroxyprogesterone $(120 \%), 11 \beta$-hydroxyprogesterone $(25 \%)$ and $20 \alpha$-dihydroprogesterone $(3.5 \%)$ for the progesterone antiserum; progesterone $(9 \%)$ and $5 \alpha$-pregnanedione $(12 \%)$ for the pregnenolone antiserum; and $20 \beta$-dihydroprogesterone $(10 \%)$ for the $20 \alpha$-dihydroprogesterone antiserum. The limits of sensitivity of the assays (per tube) were $25 \mathrm{pg}$ for progesterone and $20 \alpha$-dihydroprogesterone and $50 \mathrm{pg}$ for pregnenolone. The intra- and inter-assay coefficients of variation of all the steroid assays were each $<10 \%$ and $<16 \%$ respectively.

Statistics. Sample data derived from populations with a normal distribution, as assessed by the test of Shapiro \& Wilk (1965), were subjected to parametric statistical analysis. Unless indicated otherwise, significant differences between different treatment groups were determined by analysis of variance in conjunction with Fisher's test of least significant difference. Data showing evidence of deviation from normality were analysed non-parametrically using the Kruskal-Wallis and Friedman tests in conjunction with a multiple range test based on differences between rank sums (Zar, 1974). The level of significance was set at $P<0.05$.

\section{Results}

Effect of 6 infusion of prostaglandins on plasma progesterone concentrations

Plasma concentrations of progesterone in the control groups fell substantially during the first 1$2 \mathrm{~h}$ of infusion (Text-fig. 1) and this decline was significant in the control groups of the 6-keto-PGF-

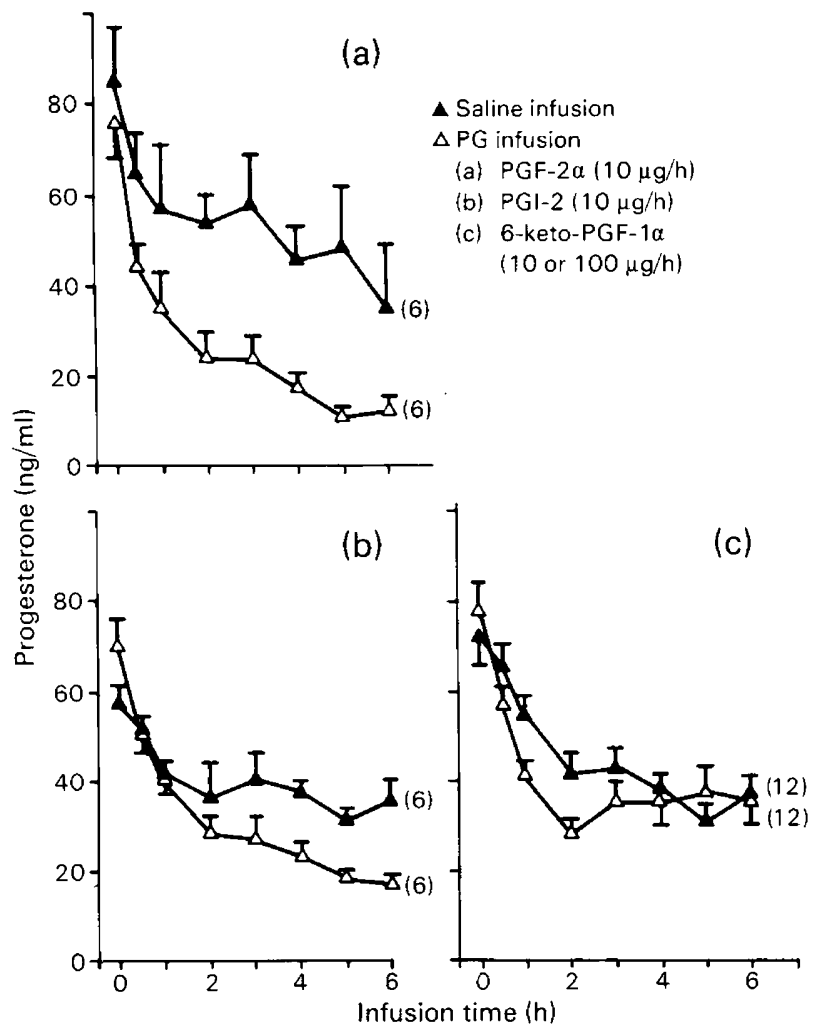

Text-fig. 1. Plasma concentrations of progesterone (mean \pm s.e.m.) for rats (no. in parentheses) during prostaglandin infusions. 
$1 \propto$ and PGI-2 studies $(P<0 \cdot 05)$. The trauma of surgery causes elevation of plasma progesterone due to stress-induced secretion of the hormone by the adrenal, and it requires $1-2 \mathrm{~h}$ for plasma concentrations to return to pre-surgical values (Meyer, Bruce \& Willcox, 1982). For the final $4 \mathrm{~h}$ of infusion, plasma progesterone concentrations remained relatively constant in each of the control groups (Text-fig. 1). Infusion of PGF- $2 \alpha$ and PGI-2 significantly reduced plasma progesterone concentrations overall, relative to their respective matched control groups $(P<0.001)$ although PGF- $2 \alpha$ was more potent than PGI-2 (Text-figs 1a \& b). Plasma progesterone concentrations were reduced significantly to $70 \%$ of control values $(P<0.05)$ within 30 min of starting infusion of PGF$2 \alpha$, but it required $4 \mathrm{~h}$ of infusion of PGI-2 to reduce plasma progesterone concentrations significantly $(P<0.05)$, relative to its controls. In 2 rats infused with $P G I-2$ at $100 \mu \mathrm{g} / \mathrm{h}$ there was a similar decline in plasma progesterone concentrations but these results were not analysed statistically. Only 2 rats were studied because, at this dosage, PGI-2 had a dramatic effect on arterial blood pressure, the levels falling from 144 to $43 \mathrm{mmHg}$ within $5 \mathrm{~min}$ of starting the infusion and remaining at this level throughout the 6-h infusion period. Infusion of 6-keto-PGF-1 $\alpha$ at 10 or $100 \mu \mathrm{g} / \mathrm{h}$ had no significant effect on plasma progesterone concentrations $(P>0.05)$ relative to the matched controls (Text-fig. 1c). The data for these 2 treatment groups and their respective controls were each pooled because their effects on plasma progesterone concentrations were not significantly different.

No significant differences were observed between each treatment group in mean \pm s.e.m. body weight of the rats $(217 \pm 3 \mathrm{~g}, n=50)$, the number of corpora lutea per rat $(13 \cdot 0 \pm 0 \cdot 3, n=50)$ or the haematocrit based on the average of all samples taken from each rat $(41 \cdot 0 \pm 0.4 \%, n=400)$.

\section{Steroid concentrations in luteal tissue and plasma after prostaglandin infusion}

The effects of the prostaglandins on luteal steroidogenesis were assessed in terms of the tissue concentrations of pregnenolone, progesterone and $20 \alpha$-dihydroprogesterone after $6 \mathrm{~h}$ of infusion, and related to the circulating concentrations of progesterone and $20 \alpha$-dihydroprogesterone at this time (Table 1). Sufficient blood to determine the plasma concentrations of both progesterone and $20 \alpha$-dihydroprogesterone was obtained only at the $6 \mathrm{~h}$ sampling immediately before the cessation of the infusion. The control data obtained from the saline-infused rats for each prostaglandin have been combined because there were no significant differences between these groups. PGF- $2 \alpha$ significantly reduced luteal tissue concentrations of progesterone and pregnenolone by $95 \%$ ( $P<$ $0.005)$ and $78 \%(P<0.025)$ respectively and doubled $20 \alpha$-dihydroprogesterone concentrations,

Table 1. Concentrations of steroids in luteal tissue and peripheral plasma after infusion of prostaglandins for $6 \mathrm{~h}$

\begin{tabular}{|c|c|c|c|c|c|}
\hline \multirow[b]{2}{*}{$\begin{array}{l}\text { Treatment } \\
(\mu \mathrm{g} / \mathrm{h})\end{array}$} & \multicolumn{3}{|c|}{ Luteal tissue (ng/mg) } & \multicolumn{2}{|c|}{ Peripheral plasma (ng/ml) } \\
\hline & Progesterone & Pregnenolone & $\begin{array}{l}\text { 20a-Dihydro- } \\
\text { progesterone }\end{array}$ & Progesterone & $\begin{array}{l}20 \alpha \text {-Dihydro- } \\
\text { progesterone }\end{array}$ \\
\hline $\begin{array}{l}\text { Saline }(23 \text { or } * 24) \\
\text { PGF- } 2 \alpha\end{array}$ & $31 \pm 4^{a}$ & $4 \cdot 5 \pm 0 \cdot 5^{a}$ & $6 \cdot 8 \pm 1 \cdot 1^{a}$ & $35 \pm 4^{* a}$ & $30 \pm 4^{* a}$ \\
\hline $\begin{array}{l}10(6) \\
\text { 6-keto-PGF-1 } \alpha\end{array}$ & $1 \cdot 5 \pm 0 \cdot 5^{b}$ & $1 \cdot 0 \pm 0 \cdot 3^{b}$ & $14 \pm 4^{a}$ & $12 \pm 3^{b}$ & $29 \pm 8^{3}$ \\
\hline $\begin{array}{c}10(6) \\
100(6) \\
\text { PGI-2 }\end{array}$ & $\begin{array}{l}18 \pm 5^{a} \\
16 \pm 6^{a}\end{array}$ & $\begin{array}{l}2 \cdot 1 \pm 0 \cdot 3^{\mathrm{a}} \\
2 \cdot 3 \pm 0.8^{\mathrm{a}}\end{array}$ & $\begin{array}{l}3 \cdot 0 \pm 1 \cdot 1^{\mathrm{a}} \\
7 \cdot 3 \pm 2 \cdot 9^{\mathrm{a}}\end{array}$ & $\begin{array}{l}36 \pm 7^{a} \\
33 \pm 7^{a}\end{array}$ & $\begin{array}{l}22 \pm 4^{a} \\
30 \pm 5^{a}\end{array}$ \\
\hline $\begin{array}{l}10(6) \\
100(2)\end{array}$ & $\begin{array}{c}15 \pm 3^{\mathrm{a}} \\
2,18\end{array}$ & $\begin{array}{l}3 \cdot 3 \pm 0 \cdot 8^{a} \\
0 \cdot 6,5 \cdot 8\end{array}$ & $\begin{array}{l}4 \cdot 7 \pm 2 \cdot 1^{a} \\
5 \cdot 4,12 \cdot 0\end{array}$ & $\begin{array}{c}17 \pm 2^{b} \\
17,23\end{array}$ & $\begin{array}{l}22 \pm 4^{\mathrm{a}} \\
16,24\end{array}$ \\
\hline
\end{tabular}

The number of determinations $(n)$ is indicated in parentheses. Values are mean \pm s.e.m. except when $n=2$ for which individual values are given. Values with different superscripts in the same column are significantly different $(P$ $<0.05$; non-parametric statistics). Groups with $n=2$ were excluded from the statistical analysis. 
although this rise was not significant $(P>0.05)$, Concomitantly, plasma progesterone concentrations were significantly reduced by $66 \%(P<0.001)$ while $20 \alpha$-dihydroprogesterone concentrations were unaltered. PGI-2 and 6-keto-PGF-1 $\alpha$ had no significant effect $(P>0.05)$ on luteal tissue steroid concentrations, although mean values were generally lower than in the control groups. Plasma progesterone concentrations were significantly reduced by $50 \%$ by PGI- $2(P<0.001)$ but not by 6-keto-PGF-1 $\alpha$. Neither prostaglandin had a significant effect on plasma $20 \alpha$-dihydroprogesterone concentrations $(P>0.05)$.

\section{Effect of PGI-2 on arterial blood pressure}

To evaluate the effect of PGI-2 on arterial blood pressure, 5 rats were cannulated as described above. PGI-2 was infused 2 to 3 times per dose per rat at rates of $2,10,20$ and $60 \mu \mathrm{g} / \mathrm{h}$ in $5 \mathrm{~min}$ pulses interspersed by 5 min pulses of buffer lacking PGI-2 (control infusate). The changes in blood pressure associated with PGI-2 infusion were assessed by comparing them to the mean pressure during the immediately preceding control period. Average changes were determined for each rat and significance tested by Student's paired $t$ test. Control blood pressures remained constant throughout the course of the experiment and ranged from $155 \pm 7 \mathrm{mmHg}$ (mean \pm s.e.m.) to $161 \pm$ $4 \mathrm{mmHg}$. PGI-2 infusion at rates of $2,10,20$ and $60 \mu \mathrm{g} / \mathrm{h}$ resulted in a progressive fall in arterial blood pressure of $4,6,15$ and $42 \%$, respectively, although only the $42 \%$ fall was statistically significant $(P<0.05)$. Maximum reduction in blood pressure occurred within the $5 \mathrm{~min}$ infusion period. Neither PGF- $2 \alpha$ nor 6-keto-PGF-1 $\alpha$ significantly affected blood pressure at infusion rates of up to $100 \mu \mathrm{g} / \mathrm{h}$.

\section{Discussion}

The results of previous studies of the effects of PGI-2 and its metabolite 6-keto-PGF-1 $\alpha$ on luteal function have been conflicting. A single subcutaneous injection of PGI-2 ( $0.1 \mathrm{mg})$ or 6-keto-PGF$1 \propto(1 \mathrm{mg})$ into the pregnant hamster reduced serum concentrations of progesterone by 40 and $88 \%$, respectively, after $6 \mathrm{~h}$ (Kimball \& Porteus, 1978). In contrast, plasma concentrations of progesterone in cows were elevated for $14 \mathrm{~h}$ following the injection of PGI-2 $(1 \mathrm{mg})$ directly into the corpus luteum while 6-keto-PGF-1 $\alpha$ was without effect (Milvae \& Hansel, 1980). The results of both studies, however, may represent pharmacological rather than physiological actions of the prostaglandins because of the high dosages used. The present finding that infusion of small amounts of PGI-2 (5 $\mu \mathrm{g}$ in $5 \mathrm{~min}$ ) provoked an immediate and substantial reduction in blood pressure is pertinent: the amounts of PGI-2 $(0 \cdot 1-1 \cdot 0 \mathrm{mg})$ administered as a single injection in the above previous studies may have provoked circulatory changes which contributed to the differences in the results obtained.

The basis of the present study was to compare the effects on luteal function of PGF- $2 \alpha$, PGI-2 and 6-keto-PGF-1 $\alpha$ under conditions as close to physiological as practicable. Therefore, prostaglandins were administered by continuous infusion rather than by bolus injection to avoid very high peak concentrations and to allow for their rapid metabolism (Piper, Vane \& Wyllie, 1970; Dusting, Moncada \& Vane, 1978). Moreover, infusion was into the dorsal aorta, rather than into the venous system to ensure that the prostaglandins underwent minimal metabolism before reaching the ovary. Under these conditions, PGF- $2 \alpha$ had a potent luteolytic effect since its infusion caused a rapid and sustained fall in plasma concentrations of progesterone and in luteal tissue concentrations of progesterone and pregnenolone (Text-fig. 1; Table 1). Although plasma concentrations of $20 \alpha$-dihydroprogesterone remained unchanged, luteal tissue concentrations doubled (Table 1), suggesting the start of increased $20 \alpha$-hydroxysteroid dehydrogenase activity which is also characteristic of luteolysis in the rat (Strauss \& Stambough, 1974).

In contrast to PGF- $2 \alpha$, there was no evidence that 6-keto-PGF-1 $\alpha$ had any luteolytic effect, even when it was infused at a 10 -fold higher rate. Plasma progesterone concentrations were not 
affected and luteal tissue concentrations of progesterone and pregnenolone were not significantly altered (Text-fig. 1; Table 1). Results from the PGI-2 infusions were intermediate between those of the other two prostaglandins in that plasma progesterone concentrations fell significantly (Text-fig. 1), albeit to a lesser extent than with PGF- $2 \alpha$ infusion, while luteal tissue steroid concentrations were not significantly affected (Table 1). The effect on plasma progesterone concentrations was not related to any hypotensive action and it was not due to metabolism of PGI-2 to 6-keto-PGF-1 $\alpha$ since the latter had no apparent action.

In conclusion, the present results show that in the pregnant rat PGI-2 has only a minor suppressive effect on luteal function compared to the potent luteolytic action of PGF- $2 \alpha$, while 6keto-PGF-1 $\alpha$, the immediate metabolite of PGI-2, is without apparent effect.

We thank Dr J. E. Pike, Upjohn Company, Kalamazoo, Michigan, U.S.A., for the prostaglandins used in this study; Dr K. P. McNatty, Wallaceville Animal Research Centre, New Zealand, for antisera to progesterone and pregnenolone; Endocrine Sciences, Tarzana, California, U.S.A. for antisera to $20 \alpha$-dihydroprogesterone: and Mrs F. Paioff and Mr A. Stuart for technical assistance. This study was supported by grants from the Australian Research Grants Committee (N.W.B.) and the King Edward Memorial Hospital Research Foundation (D.L.W.). D.L.W. is a Raine Research Fellow and K.M.H. an Australian Queen Elizabeth II Research Fellow; the financial support of these bodies is acknowledged.

\section{References}

Abel, M.H. \& Kelly, R.W. (1979) Differential production of prostaglandins within the human uterus. Prostaglandins 18, 821-828.

Abramowitz, J. \& Birnbaumer, L. (1979) Prostacyclin activation of adenylyl cyclase in rabbit corpus luteum membranes: comparison with 6-keto-prostaglandin $\mathrm{F}_{1 \alpha}$ and prostaglandin $\mathrm{E}_{1}$. Biol. Reprod. 21, 609-616.

Carr, B. R., Mikhail, G. \& Flickinger, G.L. (1971) Column chromatography of steroids on Sephadex LH-20. $J$. clin. Endocr. Metab. 33, 358-360.

Dusting, G.J., Moncada, S. \& Vane, J.R. (1978) Recirculation of prostacyclin $\left(\mathrm{PGI}_{2}\right)$ in the dog. Br. $J$. Pharmacol. 64, 315-320.

Fuchs, A.R., Mok, E. \& Sundaram, K. (1974) Luteolytic effects of prostaglandins in rat pregnancy and reversal by luteinizing hormone. Acta endocr., Copenh. 76, 583-596.

Jones, R.L., Poyser, N.L. \& Wilson, N.H. (1977) Production of 6-oxo-prostaglandin $\mathrm{F}_{1 \alpha}$ by rat, guineapig and sheep uteri in vitro. Br. J. Pharmacol. 58, 436P-437P.

Kelly, R.W. (1981) Prostaglandin synthesis in the male and female reproductive tract. $J$. Reprod. Fert. 62, 293-304.

Kennedy, T.G. \& Zamecnik, J. (1978) The concentration of 6-keto-prostaglandin $F_{1 \alpha}$ is markedly elevated at the site of blastocyst implantation in the rat. Prostaglandins 16, 599-605.

Kimball, F.A. \& Porteus, S.E. (1978) Effect of in vivo prostaglandin treatment of ${ }^{3} \mathrm{H}-\mathrm{PGF}_{2 \alpha}$ uptake in hamster corpora lutea. Prostaglandins 16, 427-432.

Meyer, G.T., Bruce, N.W. \& Willcox, D.L. (1982) Effects of handling stress and ether anaesthesia on plasma progesterone concentrations in the pregnant rat. Proc. Aust. Soc. Reprod. Biol., 14, Abstr. 10.
Milvae, R.A. \& Hansel, W. (1980) The effects of prostacyclin $\left(\mathrm{PGI}_{2}\right)$ and 6-keto-PGF ${ }_{1 \alpha}$ on bovine plasma progesterone and LH concentrations. Prostaglandins 20, 641-647.

Piper, P.J., Vane, J.R. \& Wyllie, J.H. (1970) Inactivation of prostaglandins by the lungs. Nature, Lond. 225, 600-604.

Poyser, N.L. \& Scott, F.M. (1980) Prostaglandin and thromboxane production by the rat uterus and ovary in vitro during the oestrous cycle. J. Reprod. Fert. 60, $33-40$.

Shapiro, S.S. \& Wilk, M.B. (1965) An analysis of variance test for normality (complete samples). Biometrika 52, 591-611.

Smith, S.K., Abel, M.H., Kelly, R.W. \& Baird, D.T. (1981) A role for prostacyclin $\left(\mathrm{PGI}_{2}\right)$ in excessive menstrual bleeding. Lancet i, 522-524.

Strauss, J. \& Stambough, R.L. (1974) Induction of 20๙hydroxysteroid dehydrogenase in rat corpora lutea of pregnancy by prostaglandin $\mathrm{F}_{2 \alpha}$. Prostaglandins 5, 73-85.

Sun, F.F., Chapman, J.P. \& McGuire, J.C. (1977) Metabolism of prostaglandin endoperoxide in animal tissues. Prostaglandins 14, 1055-1075.

Thorneycroft, I.H. \& Stone, S.C. (1972) Radioimmunoassay of serum progesterone in women receiving oral contraceptives. Contraception 5, 129-146.

Veldhuis, J.D., Klase, P. \& Demers, L.M. (1982) Luteinizing hormone stimulates the production of prostacyclin by isolated ovarian cells in vitro. Prostaglandins 23, 319-327.

Zar, J.H. (1974) Nonparametric multiple comparisons. In Biostatistical Analysis, pp. 156-157. Prentice-Hall, New Jersey. 